\title{
THE STUDENTS' PERCEPTION OF THE EFFECTIVENESS OF ENGLISH AND ARABIC TEACHING AND LEARNING AT THE LANGUAGE AND CULTURE CENTER OF STATE INSTITUTE FOR ISLAMIC STUDIES SHEKH NURJATI CIREBON
}

\author{
Mahmud ${ }^{1)}$, Pangesti Wiedarti ${ }^{2)}$ \\ IAIN Shekh Nurjati Cirebon ${ }^{1)}$, Yogyakarta State University ${ }^{2)}$ \\ mahmood.cliff@gmail.com ${ }^{1)}$, pangesti@uny.ac.id ${ }^{2)}$
}

\begin{abstract}
This study aimed to explore the effectiveness of English and Arabic teaching and learning the Language and Culture Center (LCC) at the State Institute for Islamic Studies Shekh Nurjati Cirebon (SIIS SNJ) based on the students' perception. The study is to find out students' opinion toward English and Arabic teaching and learning process and provide beneficial information for the teaching system in the LCC. This study used descriptive survey approach. The subjects were the students of English and Arabic intensive program. The data were collected through the questionnaire The results of the study are as follows. First, the teaching quality indicator is categorized as fairly effective. Second, the generic skills indicator is categorized as less effective. Third, students' motivation indicator is categorized as less effective. Fourth, learning resources is categorized as not effective. Fifth, the assessment appropriateness is categorized as fairly effective. Sixth, the students' workload is categorized as less effective. Seventh, the curriculum content is categorized as less effective.
\end{abstract}

Keywords: students' perception, teaching and learning, effectiveness.

\section{PERSEPSI MAHASISWA TERHADAP KEEFEKTIFAN PEMBELAJARAN BAHASA INGGRIS DAN ARAB PADA PUSAT BAHASA DAN BUDAYA DI IAIN SHEKH NURJATI CIREBON}

\begin{abstract}
Abstrak
Penelitian ini bertujuan untuk mencari keefektifan pembelajaran bahasa Inggris dan Arab pada Pusat Bahasa dan Budaya (PBB) di Institut Agama islam Negeri Shekh Nurjati Cirebon berdasarkan persepsi mahasiswa. Penelitian untuk menperoleh memcari pendapat mahasiswa terhadap keefektifan pembelajaran di $P B B$ dan menyajikan informasi yang penting buat system pembelajaran di $P B B$. Penelitian ini menggunakan pendekatan deskriptif survey. Subjek penelitian ini adalah mahasiswa dari Divisi Bahasa Inggris dan divisi Bahasa Arab. Data dikumpulkan melalui angket. Hasil penelitian adalah sebagai berikut: Pertama, good teaching masuk dalam kategori cukup efektif. Kedua, generic skills masuk dalam kategori kurang efektif. Ketiga, students' motivation masuk dalam kategori kurang efektif. Keempat, learning resources masuk dalam kategori tidak efektif. Kelima, assessment appropriateness masuk dalam kategori cukup efektif. Keenam, students' workload masuk dalam kategori kurang efektif. Ketujuh, curriculum coherence, masuk dalam kategori kurang efektif.
\end{abstract}

Kata Kunci: persepsi mahasiswa, pembelajaran, keefektifan. 


\section{INTRODUCTION}

During this decade, the State Institute for Islamic Studies Shekh Nurjati Cirebon (SIIS $\mathrm{SNJ}$ ) has been campaigning the importance of foreign language mastery particularly English and Arabic. It is based on the reality that both English and Arabic are the two main foreign languages that have strategic roles in current day. To meet this demand, The SIIS SNJ establishes the LCC as an institution that is mandated to develop students' foreign language competence, especially English and Arabic. It is expected that the LCC can be the locomotive for developing students' English and Arabic proficiency.

However, since last three years, a controversy between pros and contras for the existence of the LCC appears regarding the effectiveness of the LCC. The LCC is perceived lack of contribution in developing students' English and Arabic competence. The indications are that there is no significant progress of the students' English and Arabic qualification after they had been enrolled in the intensive program. The students' attitude in the process of teaching and learning is also indicated low enthusiasm and expectation regarding their success. In short, Students' English and Arabic competence is still so far from the expected goal.

Measuring the effectiveness of teaching and learning process certainly involves same parties and approaches. One of them is a survey based on students' experience. Evaluating the leadership and management, teaching and learning process and environments supports is necessary but conducting those three factors in the same time would be a hard work. Regarding the difficulties and the researcher limitation on some parties, the researcher is interested to involve the students in measuring the effectiveness of teaching and learning in the LCC.

Students' perception of teaching and learning effectiveness is recognized as important aspect for the evaluation of educational institutions. Ainley (2001, p.9) suggests that many educational institutions and programs require that students' views be surveyed and included in the review and appraisal processes for programs and staff. The importance of students' feedback on educational program is recognized by many educational expertises. Measuring students' satisfaction was also useful as Sidhu, (2003, p.23) stated that students' perception and observation can work in practice and become a part of exploratory studies that contribute as much to the teaching and learning process by providing suggestions and directions for future improvement.

Realizing the importance of students' perception of educational program, the researcher convinces that conducting a similar study in the LCC(LCC) at the State Institute for Islamic studies Shekh Nurjati (SIIS SNJ) Cirebon is considered useful. Moreover, measuring students' perception in the LCC is also necessary to assess the effectiveness of the teaching and learning in the LCC for some reasons. First, The LCC as a foreign language and culture development center has never involved students in evaluating the program. Second, the LCC was designed to provide foreign language Intensive program for developing students' language proficiency in the university environment, however students' satisfaction on the LCC service has not measured yet. Third, evaluating an education is not only depended on the stakeholder and decision maker but students' view also considered important.

Despite some reasons above, the researcher also takes into some considerations related to problems in the process of teaching and learning in the LCC. For three years the researcher has been an instructor in the LCC, there was no significant progress of the students' English and Arabic qualification after they had enrolled the course. Students' attitude toward the course also indicates low expectation regarding their success. They perform less enthusiasm in joining the foreign language program at the LCC. The curriculum of the LCC indicates superficial. As the researcher observed, the LCC does not have a definite curriculum. It can be seen in course books were designed by only adopted from some resources without considering students need.

With regard to the relevance of students' perception for program review and appraisal process, the researcher needs to determine appropriate instruments to explore necessary information from students. In this case, the researcher adapted the keys performance indicators of effective teaching and learning from the Course Experience Questionnaire (CEQ) by Ramsden (1993) such as teaching quality, generic skills, learning resources, students' motivation, assessments appropriateness, students' workloads, and curriculum coherence to be utilized for this research. 


\section{Literature Review}

Measuring Student Satisfaction of Teaching and Learning

The term Student satisfaction, according to Oliver \& Desarbo (in Frej \& Alkhatab, 2011, p.22) refers to the favorability of a student's subjective evaluation of the various outcomes and experiences associated with education. Jenssen et al. (2002, p.193) state that student satisfaction survey can be as a tool for building a bridge between more traditional and academic views on how to improve more market-orientated perspectives. Involving students' satisfaction in the quality of teaching insurance of an institution is accepted as full and equal partner. Students will not be able to contribute if they are ignored for providing information, making comments, or initiating appeals. According to BC College \& Institute Student Outcomes Survey $(2008$, p.2), the measurement of student satisfaction can be useful to post-secondary institutions, to help them to pinpoint their strengths and identify areas for improvement. Furthermore, Satisfaction ratings go beyond teaching assessments, which have a narrow focus, to include broader aspect of the student learning experience. To grasp the complexity of that learning experience, it is not enough to know the degree to which students are satisfied, it is important to understand the factors that contribute to student satisfaction. Marsh (in Bystrom, 2004, p.5) asserts that student ratings are clearly multidimensional, quite reliable, reasonably valid, relatively uncontaminated by many variables often seen as sources of potential bias, and are seen to be useful by students, faculty, and administrators.

According to Cambell et al. (2004, p.65), teaching and learning effectiveness measurement emphasizes the quality dimension and always about achievements of students. Scheerens (2009, p.18), explains that teaching effectiveness refers to the performance of the organizational unit called 'school', 'course', or 'program'. The performance of the school can be expressed as the output of the school, which in turn is measured in term of the average achievement of the pupils at the end of a period of formal schooling.

\section{Keys Measurements Indicators}

Teaching is a multidimensional process. It comprises of number of aspects such as students' experiences which sometimes are difficult to evaluate. However, in general teaching and learning process, aspects related to the students' experience are often influenced by combination of teacher characteristics, environment which includes physical aspects of learning resources, clear goal of curriculum, assessment appropriateness etc. In regard with the core of measuring teaching quality and learning based on students' perception, the indicators were adapted from Course Experience Questionnaire (CEQ), which was developed by Ramsden (1993). The indicators of measurements include (1) Teaching Quality, (2) Generic skills, (3) Students' motivation, (4) Learning Resources, (5) Assessment appropriateness, (6) Students' workload, and (7) Curriculum. According to Leung \& Kember (2006: 16), the CEQ was primarily designed as a performance indicator for teaching effectiveness which assesses a range of student perceptions related to teaching and learning.

First, Teaching Quality. It refers to teacher characteristic. According to Killen (2009.129), effective teacher has to be skillful to present information clearly, and able to use a variety of strategies that encourage learners to remain task-oriented and to engage the students in learning processes in which they can experience reasonably high levels of success. Ur (2009, p.13) simplifies that good teacher-made materials are relevant and personalized, answering the needs of the learners in a way no other materials can.

Second, Generic skills. According to Nunan et al. (2000, p.81) identify four main categories of skills relates to the discipline specific knowledge that underpins the course of study. Hyland (2006, p.12) states that the issue of generic skills and language teaching also rises the question of what it is that students are actually learning.

Third, Students' Motivation. According to Wlodwoski (in Root 2010, pp.1-2), motivation is the processes that can (a) arouse and instigate behavior, (b) give direction or purpose to behavior, (c) continue to allow behavior to persist, and (d) lead to choosing or preferring a particular behavior". In instructional process, motivation to learn is paramount to student success. Krashen (in Weisman \& Carmen, 2006, pp.6869) suggests that the three most important elements related to success in a second language are (1) a low anxiety environment, (2) high motivation, and (3) self-confidence and selfesteem. 
Fourth, Learning Resources. Gedgrave (1999, p.85) classifies the learning supports for convenience of study into some categories; Audio aids, Visual aids, and Audio-visual aids.

Fifth, Assessment Appropriateness. Shepard (in Jones, 2003, p.11) explains that the primary purpose of assessment is to provide the teacher with information that can be used to guide and improve instruction. Cameron (2005, p.222) defines that assessment is concerned with pupils' learning or performance, and thus provide one type of information that might be used in evaluation, testing is particular form of assessment, that is concerned with measuring learning trough performance.

Sixth, Students' Workload. Kember et al. (in Tampakis \& Votiratos, 2009, p.2) states that workload is directly connected to learning and teaching procedure in every field of the education. The definition of workload itself according to Ramsden (in Tampakis \& Votiratos 167), is aspect related to the pressure placed on students of demands of the syllabus and assessment task.

Seventh, Curriculum Content. , Pincas et al. (2003, p.39) state that the curriculum decision of English language teaching requires are made about what is to be taught, the process of selection, and about the breaking down of that body of knowledge or skills into teachable units. Kumaravadivelu, (2006, p.75)., curriculum is the essential component of any language teaching program which specifies the content of language learning and teaching.

\section{RESEARCH METHOD}

This study was conducted at the LCC at the SIIS SNJ Cirebon. The subjects were the students from both English and Arabic divisions. This reasearch was qualitative descriptive method. The data were investigated though the survey approach. The instrument used is a questionnaire.

Regarding the number of students which is approximately 2440 students, the sumple was determined due to time limitation of the research, cost efficiency and impossibility of the researcher to investigate whole population. Random sampling was employed to identify information-rich participants for the investigation and to avoid from subjectivity. The sampling technique was determined by using proportionate stratified random sampling. The sumple from both divisions is 125 students for the English Division and 120 students for the Arabic students was 120 .

\section{Research Site}

The research was conducted in the LCC from July to September 2012 after both English and Arabic divisions had performed the intensive language program. On July $14^{\text {th }}$, the researcher gave the research permit letter over to the Head of LCC. The researcher took the data from the staff on July $21^{\text {st }}$.

\section{Research Instrument}

The instrument was assessed for the content validity was by the expert judgment. The realiability was tested by using SPSS. 17.00 for windows. It was conducted as an approach for soliciting the opinions from individual with particular expertise and qualified in this field. The value which the instrument considers as reliable is at least 0.70 . This follows the suggestion of Mardapi (2004, p.46) about reliability coefficient with minimum score of 0.70 .

Seven indicators of the survey were designed. It consists 35 items of seven indicators namely (1) teaching quality, (2) students' workload, (3) assessment appropriateness, (4) generic skills, (5) intellectual motivation,(6) learning resources, and (7) curriculum content. Despite the 35 questions, the open-ended questionnaire was also involved in each indicator. It was purposed to attain more information that could not be found by the questionnaire. Of the 35 items were structured into multi-indicator items, requiring the respondent to choose an option from a 1 or 5 points scale. The items were designed in a selected-response format where respondents had to checklist one response from a five point Likert scale; 5=Strongly Agree, 4=Agree, 3=Moderate, 2=Disagree, and $1=$ Strongly Disagree.

\section{Data Analyzing Technique}

Both qualitative and quantitative techniques were employed. To interpret the level of the mean scores, the researcher looked at the frequency, percentage, and mean scores directly from the 5-point Likert scale. The criteria were based on the interpretation area and sorted into four criteria by Mardapi (2008, p.122) advocated that the display of measurement depends on the evaluator, and the result of the measurement which need some specific criteria. The effectiveness scale was the criteria that the researcher utilized regarding the need of this research as can be seen in the following table. 
Table 1. The Criteria of Effectiveness

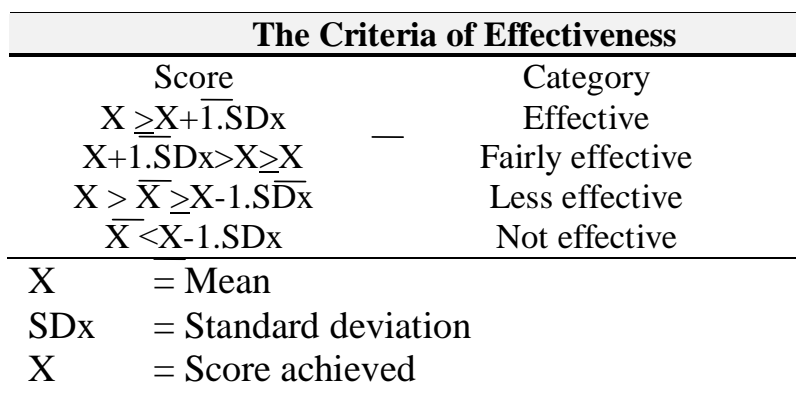

\section{RESEARCH FINDINGS AND DISCUSSIONS}

\section{Teaching Quality (TQ)}

Based to table below, general trend indicates that the students in English division (ED) positively responded the TQ, hit by 3.11 as mean score of the overall items. The TQ was categorized fairly effective. It can also be seen at the score of each item where item 1 was 3.05 , item 3 was 3.52 , item 5 were 3.05 , and item 6 acquired 3.28. Those four indicators were categorized fairly effective. Furthermore, items 2 and 4, acquired similar score. Each item score was 2.88 , lower than others. Hence, both items were categorized less effective.

Table 2. The Statistics Data of TQ in ED

\begin{tabular}{cccc}
\hline \multicolumn{4}{c}{ The Statistics Data of TQ in ED } \\
\hline Item & N & Score & Category \\
\hline Item 1 & 125 & 3.05 & Fairly effective \\
Item 2 & 125 & 2.88 & Less effective \\
Item 3 & 125 & 3.52 & Fairly effective \\
Item 4 & 125 & 2.88 & Less effective \\
Item 5 & 125 & 3.05 & Fairly effective \\
Item 6 & 125 & 3.28 & Fairly effective \\
The average score & 3.11 & Fairly effective \\
\hline
\end{tabular}

The TQ had similar score with the TQ score from students in ED in term of students' perception of the satisfaction. As displays by the table below, the fairly effective category was the category for the TQ, scored by 3.7 as the mean score of the students' response of all TQ items. For every single item, there was only item 2 which was categorized not effective, hit by 2.00 . The four items respectively; item 4 , item 5 , item 6 , item 3 and item 1 achieved 3.08, 3.17, 3.07 and were categorized fairly effective. Meanwhile, item 3 achieved 3.53 and categorized effective.
Table 3. The Statistics Data of TQ in AD

\begin{tabular}{cccc}
\hline \multicolumn{4}{c}{ The Statistics Data of TQ in AD } \\
\hline Item & $\mathbf{N}$ & Score & Category \\
\hline Item 1 & 120 & 3.32 & Fairly effective \\
Item 2 & 120 & 2.00 & Not effective \\
Item 3 & 120 & 3.53 & Fairly effective \\
Item 4 & 120 & 3.08 & Fairly effective \\
Item 5 & 120 & 3.17 & Fairly effective \\
Item 6 & 120 & 3.23 & Fairly effective \\
\hline The average score & 3.07 & Fairly effective \\
\hline
\end{tabular}

In regard to determination of the students' perception of TQ in the LCC, the mean score of both TQ in ED and AD were calculated and scored 3.09. It was indicated that teaching quality in the LCC was fairly effective.

Table 4. The TQ Score

\begin{tabular}{ccc}
\hline Indicator & Score & Category \\
\hline The TQ in ED & 3.11 & Fairly effective \\
The TQ in AD & 3.07 & Fairly effective \\
TQ Score & 3.09 & Fairly effective \\
\hline
\end{tabular}

As investigated in the students' answers, the result of survey in the ED indicated that the students were satisfied with the TQ. As the Statistics data described, four of six items were categorized fairly effective. The overall score was ranged highly from 2.88 to 3.52 . It can also be stated that in general teachers in ED had fit the needs of aspects of effective teaching for some aspects.

If it comes to the open-ended question for overall satisfaction of the teaching quality, general trend seemingly addressed to the teacher's personality performance, such as teacher creativity in term of pedagogical aspect. It is also in accordance with item 2 stating "the staff was interesting in presenting the subject material" and item 4 stating "in every meeting, the target of learning is clear" where both items score were the lowest of others. S.A (student of PGMI., Smt. 4) commented in her answer for open-ended questionnaire that metode pengajaran terlalu monoton, tidak bervariasi. The similar comment was also stated by I.M. (student of PBI., Smt. 2) that sebaiknya dosen menggunakan media pembelajaran yang variatif. Based on both comments above, it can be concluded that even overall satisfaction indicators achieved the level of effectiveness, in a particular aspect, teachers should develop their pedagogical performance to encourage more effective teaching. Neil (1991) states that defining an effective teacher involves two important components in teaching and learning 
process called "teacher knowledge of the subject to be taught" and "skills in how to teach that subject." It is intuitively obvious that effective teachers must possess a professional knowledge base and exhibit knowledge of the subject matter. Successful teachers have a lot of instructional strategies and techniques that reflect their knowledge of the subject.

A little bit similar with the finding in the students from $\mathrm{AD}$ where the students more highlighted on teacher's presentation. Item 2 was also perceived negatively. In accordance with the open-ended comment, some students' statements were also indicated supporting the Statistics finding. N.F (student of PBA., Smt. 2) stated "Belajarnya bikin ngantuk", another similar comment was "Dosen ngajarnya kurang menarik" (quoted from M.B, student of PBI, Smt. 4).

In regard to the finding above, the quality of teaching in both divisions was statistically fairly effective. However, based on students need, some aspects should be improved in order to be more successful in the process of teaching and learning such as pedagogical competence includes classroom activity, teaching strategy, mechanism, and motivating students are key components for good teaching that teacher in LCC need to improve. As stated by Gregory \& Chambers (2006: 40) that teaching is as a mean to an end-a complex of activities, strategies, mechanisms, invitations, stimuli and rhetorical ploys designed to help students learn and to become better learners.

\section{The Generic Skills (GS)}

The second is the Generic skills (GS). Based on the Table below, the GS item score was 2.53 and categorized less effective. In respect to each item score, item 8 and item 9 acquired the lowest score hit by 2.48 , and respectively followed by item 6 and item 10 acquired 2.56. Meanwhile, item 7 achieved highest score with 2.59. All of items of GS in ED were categorized less effective.

Table 5. The Statistics Data GS in ED

\begin{tabular}{cccc}
\hline \multicolumn{4}{c}{ The Statistics Data GS in ED } \\
\hline Item & N & Score & Category \\
\hline Item 7 & 125 & 2.56 & Less effective \\
Item 8 & 125 & 2.59 & Less effective \\
Item 9 & 125 & 2.48 & Less effective \\
Item 10 & 125 & 2.48 & Less effective \\
Item11 & 125 & 2.56 & Less effective \\
The average score & 2.53 & Less effective \\
\hline
\end{tabular}

The students from AD responded similar perception. The general trends of this survey categorized the GS in AD as less effective. The score of the GS was only 2.43 a bit higher than 2.40 as the limit margin for 'not effective' category. The every single item; item 7 , item 10 , and item 9 , was scored by $2.34,2.37,2.40$, and respectively referred to 'not effective' category. Whilst item 11 and item 8 were scored 2.5, and 2.54, and also categorized less effective.

Table 6. The Statistics Data of GS in AD

\begin{tabular}{|c|c|c|c|}
\hline \multicolumn{4}{|c|}{ The Statistics Data of GS in AD } \\
\hline Item & $\mathbf{N}$ & Score & Category \\
\hline Item 7 & 120 & 2.34 & Less effective \\
\hline Item 8 & 120 & 2.54 & Less effective \\
\hline Item 9 & 120 & 2.40 & Less effective \\
\hline Item 10 & 120 & 2.37 & Less effective \\
\hline Item11 & 120 & 2.56 & Less effective \\
\hline The ave & core & 2.43 & Less effective \\
\hline
\end{tabular}

The calculated mean score of both GS from $\mathrm{ED}$ and $\mathrm{AD}$ was presented by the following table where the score was 2.55 . It can be concluded that statistically the GS in the LCC was categorized less effective.

Table 7. The GS score

\begin{tabular}{ccc}
\hline Indicator & Score & Category \\
\hline The GS in ED & 2.53 & Less effective \\
The GS in AD & 2.45 & Less effective \\
The average score & 2.45 & Less effective \\
\hline
\end{tabular}

In accordance with the survey result, the finding about generic skills of students in ED could be assumed that the development of English and Arabic language skills were not optimal. The indications were based on the Statistics data which range only from 2.48 to 2.59, a criterion of less effective. The similar perception was also perceived by the students in $\mathrm{AD}$, scoring 2.43 .

Furthermore, referring to the students' short comments in open-ended questionnaire, overall statement indicated that students a bit disagree with this subsection survey. Most students' comments supported their survey answer, such as N.M (student of PGMI., Smt. 4) "Selama 2 semester ikut intensive, saya kurang memperoleh hasil yang maksimal.", A.M (student of PBA., Smt. 4) "Sedikit sedikit saya bisa Bahasa Inggris, daripada sebelum ikut intensive.", and B.M. (student of PGMI., Smt. 4) "Saya ga bisa bisa Bahasa Arab, padahal dah ikut intensive.". 
As written in the curriculum of LCC that students were expected to; (1) be able in understanding in both English and Arabic Literature in basic level, (2) be able to use both Arabic and English as daily communication, (3) be competent in both English and Arabic writing skills in basic level. However, based on the findings about the GS, it was surprising that basically the purpose of establishing the LCC was to develop students' foreign language skills, but in fact, as students recognized that the foreign language intensive program still cannot reach the goal.

Regarding this phenomenon, the concept of generic language skills should be briefly stated in the curriculum of LCC. As Curriculum Development Council and the Hong Kong Examinations and Assessment Authority (CDCHKEAA, 2007, p.3) stated that The English Language curriculum framework should comprises a set of interlocking components including: subject knowledge and skills, which are expressed in the form of learning targets in the interpersonal, knowledge and experience strands, as well as learning objectives such as generic skills and attitudes.

\section{Students' Motivation (SM)}

The third indicator focused on the students' motivation. According to the result taken from the students in $\mathrm{ED}$, the $\mathrm{SM}$ was indicated 'less effective'. The only one category of overall indicators of the survey, there was no item categorized higher then less effective category. The score of each item was generally low. The highest score was achieved by only item 14, scoring 2.88 and the lowest score achieved by both item 11 and item 12 acquired 2.72 followed by item 15 achieved 2.75 and item 16 achieved 2.56.

Table 8. The Statistics Data of SM

\begin{tabular}{|c|c|c|c|}
\hline \multicolumn{4}{|c|}{ The Statistics Data of SM } \\
\hline Item & $\mathbf{N}$ & Score & Category \\
\hline Item 12 & 125 & 2.72 & Less effective \\
\hline Item 13 & 125 & 2.72 & Less effective \\
\hline Item 14 & 125 & 2.88 & Less effective \\
\hline Item 15 & 125 & 2.75 & Less effective \\
\hline Item 16 & 125 & 2.56 & Less effective \\
\hline The avera & ore & 2.72 & Less effective \\
\hline
\end{tabular}

For the students' perception of SM taken from $\mathrm{AD}$, the score of $\mathrm{SM}$ was perceived positively. It was indicated by the data display. Of the five indicators, four items were categorized fairly effective, respectively, item 12, item 13, item 14, and item 15, scoring 3.21, $3.37,4.34$, and 3.1. The only item 11 that was categorized less effective, scored by 2.95 .

Table 9. The Statistics Data of SM in AD

The Statistics Data of SM in AD

\begin{tabular}{ccrc}
\hline Item & $\mathbf{N}$ & Score & Category \\
\hline Item 12 & 120 & 2.95 & Less effective \\
Item 13 & 120 & 3.21 & Fairly effective \\
Item 14 & 120 & 3.37 & Fairly effective \\
Item 15 & 120 & 4.34 & Effective \\
Item 16 & 120 & 3.10 & Fairly effective \\
\hline \multicolumn{2}{l}{ The average score } & 3.20 & Fairly effective \\
\hline
\end{tabular}

The estimation of the SM from both ED and $\mathrm{AD}$ were calculated to find out the mean score. The result can be generalized as less motivated, as described by the following table.

Table 10. The SM score

\begin{tabular}{ccc}
\hline Indicator & Score & Category \\
\hline The SM in ED & 2.74 & Less effective \\
The SM in AD & 3.20 & Fairly effective \\
The average score & 2.97 & Less effective \\
\hline
\end{tabular}

As demonstrated by the questionnaire result, the finding of students' motivation toward the English and Arabic intensive programs indicated that the students in ED were less motivated in joining the course. The data were referred from the mean of overall score 2.74. However, in a certain item, the students tended to agree with the statements of item 14 "The staff here always effort to encourage my enthusiast in learning English", scoring 2.88, it indicated that the staffs had highly committed on what they have to do in encouraging students motivation.

Regarding the open-ended comment, the students' perception of learning motivation in ED was mostly revealed by the students' background. Most of students which were not from language education major tended to be less motivated to join the course, as found in one of the students' open-ended comment: Saya ga tertarik balajar Bahasa Inggris karena jurusan Saya bukan Bahasa Inggris (quoted from A.F, PGMI., Smt. 4), and "Sebenernya Saya terpaksa ikut belajar intensive, karena takut ga lulus", (TT, PBA., Smt. 4). In different perception was quoted from a student of English education major; "Saya senang belajar intensive, buat nambah nambah pengetahuan (T.F, PBI., Smt. 4). Another comment; Sebenernya saya males belajar ikut intensive, Bete (N.S., PBA., Smt. 4).

In different side, the students from $\mathrm{AD}$ were indicated fairlysmotivated to join the 
Arabic intensive program, ranged from 2.95 to 4.34 , the score of all items, and was categorized fairly effective. In regard to item 15 which achieved the highest score (4.34) of all items, the item asked the respondents to response the staffs' role in encouraging the students enthusiasm in learning Arabic, resulting that the staffs seemingly succeed in developing the students' motivation. According to the result of the openended comment, most of students gave positive comments for $\mathrm{SM}$ in $\mathrm{AD}$. As quoted from the finding, stated "Saya semangat belajar Bahasa Arab agar saya bisa mengerti Alquran" (R.N.K, PBA., Smt. 2), "Saya belajar intensive karena Bahasa Arab bermanfaat sih (Riza F.T, PGMI., Smt. 2) and "Saya suka belajar Bahasa Arab biar bisa ngomong Bahasa Arab" (N. Y., PGMI., Smt. 2).

Summarizing the findings above, even the students from $\mathrm{AD}$ were motivated to join the course, some efforts to encourage the students' motivation for those in English Division need to be performed. Introducing English as an important foreign language and designing teaching and learning process interestingly might develop students' enthusiasm in learning. Dornyei (2001, p.72) stated that if we could somehow make the learning process more stimulating and enjoyable, that would greatly contribute to sustained learner involvement, it should be particularly the role of teachers that they have to be aware that motivating students is a key to achieve the teaching goal.

\section{Learning Resources (LR)}

The fourth subsection of the student's perception of the English intensive program was focused on the learning resources indicator. Based on Statistics description, it was indicated that the learning resources were not adequate to support students learning needs. The students in ED entirely perceived that LR were not effective, scoring with 2.10 , a score which is lower than 2.40 as the lowest margin criteria for 'not effective category'. Overall items of the learning resources indicators for the students in ED were also cited as not effective, scoring 2.19 for item 17, 2.08 for item 18, 1.89 for item 19, 2.16 for item 20, and 2.10 for item 21 .
Table 11. The Statistics Data of LR ED

\begin{tabular}{cccc}
\hline \multicolumn{4}{c}{ The Statistics Data of LR ED } \\
\hline Item & N & Score & Category \\
\hline Item 12 & 125 & 2.19 & Not effective \\
Item 13 & 125 & 2.08 & Not effective \\
Item 14 & 125 & 2.98 & Not effective \\
Item 15 & 125 & 2.16 & Not effective \\
Item 16 & 125 & 2.10 & Not effective \\
The average score & 2.10 & Not effective \\
\hline
\end{tabular}

The other respondents were the students from AD. The students showed dissatisfaction toward the LR. The score of the overall students' response of LR was indicated as less effective, hit by 2.26 . For detail of item score indicated that each item was not effective. The highest score of all items was achieved by item 20 with 2.38 and categorized as not effective. For the lowest score was achieved by item 18 with 2.10 and indicated also as not effective, while item 16 that achieved 2.21, item 17 achieved 2.33, and item 19 achieved 2.20 were also categorized not effective. The following table illustrates the description of the data.

Table 12. The Statistics Data of LR in AD

\begin{tabular}{cccc}
\hline \multicolumn{4}{c}{ The Statistics Data of LR in AD } \\
\hline Item & N & Score & Category \\
\hline Item 12 & 120 & 2.31 & Not effective \\
Item 13 & 120 & 2.33 & Not effective \\
Item 14 & 120 & 2.10 & Not effective \\
Item 15 & 120 & 2.20 & Not effective \\
Item 16 & 120 & 2.38 & Not effective \\
The average score & 2.26 & Not effective \\
\hline
\end{tabular}

In regard to the criterion of the LR in the LCC, the mean score of both respondents from $\mathrm{ED}$ and $\mathrm{AD}$ was calculated, resulting that $\mathrm{LR}$ score was 2.18. It indicated that LR in the LCC was not effective. The detail description can be seen in the following.

Table 13. The LR Score

\begin{tabular}{ccc}
\hline Indicator & Score & Category \\
\hline The LR from ED & 2.26 & Less effective \\
The LR in AD & 2.10 & Not effective \\
The average score & 2.18 & Not effective \\
\hline
\end{tabular}

As findings were presented in the previews Statistics description, the students from both $\mathrm{ED}$ and $\mathrm{AD}$ had shown the dissatisfaction with the learning resources available in the LCC. All statements for the indicator of learning resources aspects presented in the survey questionnaire were perceived by disagreement from the students' responses, such as (1) audio-video visual equipments (2) multimedia resources and 
internet, (3) language laboratory, and (4) library. Referring to the score of the indicators above, seemingly the language intensive program was not supported by adequate learning resources.

As the finding was investigated, the openended comment showed that students generally commented on the feasibility of the language laboratory use. They acknowledged that the language laboratory was less effective for their learning. Quoted from some students' comments; "Selama belajar intensive saya ga pernah masuk lab bahasa" (A.S, PBI., Smt. 4), "Lab Bahasa cuma satu, itupun dah rusak" (M.I., MEPI., Smt. 4) indicated that language laboratory in LCC did not suit to the leaning needs.

Based on the findings above, the language laboratory is needed for supporting the students during the English and Arabic intensive program. It becomes one of the perquisites for the LCC to make the teaching and learning process more effective. Principally, language laboratory use influences directly on the effec-tiveness of teaching. It can be used as authentic listening activities, such as to listen and to respond recording tasks, pair dialoguing and interactive web site activities. Kilickaya (in Brenes 2006: 1) explains that language learners are better with authentic material that helps them to involve in a real language.

\section{Assessment Appropriateness (AA)}

As displayed in the table below, Overall items of the assessment appropriateness (AA) indicators were categorized fairly effective. The finding presented that the AA score was 3.02, indicated higher than 2.40 as the margin of the degree of effectiveness. Each item also significantly reached sufficient score for the effective criteria. Even though Item 21 and 24 achieved low score, hit by 2.70 and 2.98 , and were categorized less effective, but item 25, item 23 , item 22 achieved 3.07, 3.15, and 3.16, and respectively indicated fairly effective. At the following table can be seen the detail score for each item.
Table 14. The Statistics Data of AA in ED

\begin{tabular}{cccc}
\hline \multicolumn{4}{c}{ The Statistics Data of AA in ED } \\
\hline Item & N & Score & Category \\
\hline Item 22 & 125 & 2.70 & Less effective \\
Item 23 & 125 & 3.16 & Fairly effective \\
Item 24 & 125 & 3.15 & Fairly effective \\
Item 25 & 125 & 2.98 & Less effective \\
Item 26 & 125 & 3.07 & Fairly effective \\
The average score & 3.02 & Fairly effective \\
\hline
\end{tabular}

The similar response for AA was also perceived by the students from $\mathrm{AD}$, hit by 4.00 . However, the score of each item was perceived differently. Three items were indicated fairly effective, respectively; item 23 hit by 3.13 , item 24 hit by 3.1, item 26 hit 3.03. Only two items; item 22 and item 25, scoring with 2.76, and 2.95 were categorized less effective.

Table 15. The Statistics Data of AA in AD

\begin{tabular}{|c|c|c|c|}
\hline \multicolumn{4}{|c|}{ The Statistics Data of AA in AD } \\
\hline Item & $\mathbf{N}$ & Score & Category \\
\hline Item 22 & 120 & 2.76 & Less effective \\
\hline Item 23 & 120 & 3.13 & Fairly effective \\
\hline Item 24 & 120 & 3.1 & Fairly effective \\
\hline Item 25 & 120 & 2.95 & Less effective \\
\hline Item 26 & 120 & 3.03 & Fairly effective \\
\hline \multicolumn{2}{|c|}{ The average score } & 4.01 & Fairly effective \\
\hline
\end{tabular}

In regard to the criterion of the overall score of LR, the calculation from both respondents from $E D$ and $A D$ resulted 2.55. It was indicated that AA was fairly effective. The detailed description can be seen in the following table.

Table 16. The AA Score

\begin{tabular}{ccc}
\hline Indicator & Score & Category \\
\hline The AA in ED & 3.02 & Fairly effective \\
The AA in AD & 4.00 & Fairly effective \\
The average score & 3.51 & Fairly effective \\
\hline
\end{tabular}

In regard to the findings of the questionnaire, the AA score from the respondents from $\mathrm{ED}$ which ranged from 2.70 to 3.16 was categorized fairly effective. The same indicator was also found that $\mathrm{AA}$ score in $\mathrm{AD}$ was categorized fairly effective. The range of the score was 2.76 to 3.13. However, students from both $\mathrm{ED}$ and $\mathrm{AD}$ perceived similar response for item 22 and item 25, they tended to disagree with the statement of item 22 "Staff always use some type of assessment to measure the learning result"(item 22) and "Test/examination really measure my understanding"(item 25).

Based on the findings from the students' short comments, in both $\mathrm{ED}$ and $\mathrm{AD}$, there were 
various opinions about the appropriateness of assessment. Some students commented on the heaviness of assessment such as "Ujiannya terlalu berat, jangan hapalan terus"(quoted from T.S., IPA., Smt. 4), "Menurut saya sebaiknya jangan terlalu banyak PR" (M.A.D. MAT., Smt. 2). Some students also asserted on pass/fail system of marking such as "Kelulusan jangan diukur dari hasil semester saja, kerajinan, keaktifan juga harusnya jadi pertimbangan dong” ( A.M., IPS., Smt. 4) “Menurut saya kerajinan dan keaktifan dikelas juga harusnya jadi pertimbangan kelulusan" ( F.M.I, Bio., Smt. 2).

Concluding from the findings above, assessments in ED and AD seemingly tended to use the summative type which only contributes to text marks and academic reports. Whereas, the formative test is also considered very important in order to make decisions about what actions to take to promote further learning.

\section{Students' Workload (SW)}

As shown in Statistics description, the score of SW obtained from ED was categorized fairly effective which indicated by the mean of the SW items score that attained 3.06. Each item of the SW was differently responded. It can be seen where item 30 achieved 2.87 and item 27 achieved 2.89 and categorized less effective. Meanwhile, item 28 was scored with 3.24 and item 29 with 3.27. Both item 28 and 29 were categorized fairly effective.

Table 17. The Statistics Data of SW in ED

\begin{tabular}{cccc}
\hline \multicolumn{4}{c}{ The Statistics Data of SW in ED } \\
\hline Item & N & Score & Category \\
\hline Item 27 & 125 & 2.89 & Less effective \\
Item 28 & 125 & 3.24 & Fairly effective \\
Item 29 & 125 & 3.27 & Fairly effective \\
Item 30 & 125 & 2.87 & Less effective \\
The average score & 3.06 & Fairly effective \\
\hline
\end{tabular}

According to the Statistics data, the SW was indicated less effective scoring with 2.80. There was only item 29, hit by 3.26 that categorized fairly effective. Whilst the other items; item 27, item 28, and item 30 were categorized less effective, hit by $2.75,2.67$, and 2.52 .
Table 18. The Statistics Data of SW in AD

\begin{tabular}{cccc}
\hline \multicolumn{4}{c}{ The Statistics Data of SW in AD } \\
\hline Item & $\mathbf{N}$ & Score & Category \\
\hline Item 22 & 120 & 2.75 & Less effective \\
Item 23 & 120 & 2.67 & Less effective \\
Item 24 & 120 & 3.26 & Fairly effective \\
Item 25 & 120 & 2.52 & Less effective \\
The average score & 2.80 & Less effective \\
\hline
\end{tabular}

The overall score of both SW in ED and $\mathrm{AD}$ was 2.55. It was indicated that $\mathrm{SW}$ in the LCC less effective.

Table 19. The SW Score

\begin{tabular}{ccc}
\hline Indicator & Score & Category \\
\hline The SW in ED & 3.06 & Fairly effective \\
The SW in AD & 2.80 & Less effective \\
The average score & 2.93 & Less effective \\
\hline
\end{tabular}

Referring to the students' short comments, most of students from ED gave positive statements. It can be seen from some quoted statements such as A.J. (student of PBA., Smt. 4)" Sebenernya tugas tugas ga terlalu berat, cuma saya males ngerjainnya". R.P.( student of IPA., Smt. 4) "Tugas tugas banyak tapi saya bisa kerjakan smuanya" Z.M. (PBA., Smt. 4) "Tugas tugas intensif Bahasa Inggris ga seberat waktu diintensif Bahasa Arab, bikin mumet".

However, if it comes to item 27 and item 30 of the SW survey indicators, the students seemed to disagree with the two statements related with time availability for students to finish their workload. It indicated that the appropriateness of students' workload for the time availability to do their workloads needs to be highlighted. Comparing between students' comments with the score of item 27 and 30, there seems no correlation between level of workload difficulty and time availability, but inappropriate time given for students' workload becomes another burden for them.

A different perception of students' workload was found in the students from AD. General trend leads to the disagreement toward the appropriateness of workload. The Statistics data informed that some survey indicators related to workload appropriateness was responded negatively. If it comes to the specific statements of the survey, the students from AD were seemingly burdened by the amounts of workloads. If it comes to each item statements of the SW, students seemed needs much time to their works, as item 27 indicated. The Arabic language was also something new for them as 
they agree that there were many things need to understand. They were also burdened with the limitation of their time availability due to some workloads from their own study program.

Based on the students' open-ended responses, complaining on the heaviness of workload was the majority response. Difficulty of Arabic hand-script ability, vowel-less word (huruf tanpa harakat), and many assignments to memorize were the most aspect complained by students. "Tugasnya kebanyakan ngapalin" (W.T., AF., 2), "Paling males kalo suruh ngapalin mufrodat, dah banyak, susah lagi". (D.S., IPA., Smt. 4), "Belajar bahasa Arab susah nulis sama bacanya"(F.N., Adadin. 2).

As students' workload was perceived as less effective, the evaluation and reconstruction of workload seems to be executed by the stakeholder. As complained by the students from AD, they feel sustained by the amount of assignments that involve their memory. Teachers should be wise to determine assignments for their students. Some students might recognize Arabic as new subject. Too heavy workload for students does not imply on their achievements. Kember (2004, p.165) stated that heavy assessment workloads may lead to surface learning.

\section{Curriculum Content}

The last indicator of the questionnaire focused on the curriculum content. Table below displays that the score in this indicator was categorized less effective, hit by 2.88 . For each item, the CC was perceived differently such as Item 31 achieved 2.79, item 34 achieved 2.69, and item 35 achieved 2.68, and categorized less effective. The highest score of all items was achieved by item 32 , hit by 3.24 , followed by item 33 with 3.04. Both items were categorized as fairly effective.

Table 20.The Statistics Data of CC in ED

\begin{tabular}{lccc}
\hline \multicolumn{4}{c}{ The Statistics } \\
\hline Item & Data of CC & in ED \\
\hline Item 31 & 125 & 2.79 & Category \\
Item 32 & 125 & 3.24 & Fairly effective \\
Item 33 & 125 & 3.04 & Fairly effective \\
Item 34 & 125 & 2.69 & Less effective \\
Item 35 & 125 & 2.68 & Less effective \\
The average score & 2.88 & Less effective \\
\hline
\end{tabular}

Based on the data display, the students from $\mathrm{AD}$ did not also perceive the $\mathrm{CC}$ positively. The score of the $\mathrm{CC}$ was only 2.52 and categorized less effective. Overall items of CC were cited less effective, scoring 2.60 for item
31, 2.61 for item 32, 2.40 for item 33, 2.54 for item 34, and 2.45 for item 35 .

Table 21. The Statistics Data of CC in AD

\begin{tabular}{llll}
\hline \multicolumn{4}{c}{ The Statistics } \\
\hline Item & Data of CC in AD & Score & Category \\
\hline Item 31 & 120 & 2.60 & Less effective \\
Item 32 & 120 & 2.61 & Less effective \\
Item 33 & 120 & 2.40 & Less effective \\
Item 34 & 120 & 2.54 & Less effective \\
Item 35 & 120 & 2.45 & Less effective \\
\multicolumn{2}{l}{ The average score } & 2.52 & Less effective \\
\hline
\end{tabular}

The overall score of CC in the LCC, the sum of both score of students in ED and the students from $\mathrm{AD}$ were calculated and the result was 2.55. It was categorized as less effective.

Table 22.The Overall CC Score

\begin{tabular}{ccc}
\hline Indicator & Score & Category \\
\hline The CC in ED & 2.88 & Less effective \\
The CC in AD & 2.52 & Less effective \\
The average score & 2.70 & Less effective \\
\hline
\end{tabular}

As can be seen in the survey result, the Statistics data presented that students from ED perceived the curriculum as less effective, indicated by the score of the $\mathrm{CC}$ in overall items. When it come to each item, the students from ED tended to be a bit satisfied with item 32 for their perception of the themes of the course book which was considered interesting and up to date and item 33 for their perception of the balance of the language skills that available in the course book. For the other three aspects of the curriculum such as (1) the statements about the relevance of the course book toward the students' learning need (item 31), (2) the statement about practical use of the course book (item 34), and (3) the statement about reasonability of competence standard (item 35), the students tended to a bit disagree.

In regard to the students' opinions toward the course book', based on their short comments, some students pointed out that the course book lack of covering the language skills. I.D (MTK., Smt. 4) stated that " Materi listening nggak ada yang bertema Islami, membosankan". A.F., (student from PBI., Smt. 4) advocated "Banyak Unit Unit yang ga ngerti". R.B., (student from PBI., Smt. 4) also supported the above statement as he stated that "Materi listening kurang banget.

The students from AD also perceived the $\mathrm{CC}$ negatively. The Statistics explained that no item was categorized higher than less effective, 
where the score was ranged from 2.40 to 2.60 . In respect to the students' short comment, many students did not give appropriate comments. There were only some students whose comments can be quoted. T.F., (student from MEPI., Smt. 2) for example, he stated "Tema tema pada buku pedoman bagus tapi banyak yang ga ngerti”. N.F., (IPA., Smt. 2) stated " $G a$ ada listeningnya. S.M., (student from IPA., Smt. 2) stated "Isi buku sebenernya bagus, tapi sayang ga pernah praktek listening". From the students' statements above, it can be concluded that the course book need to consider on students needs. The students' needs the course book contents that cover relevant topic contents. The students also wanted that course book more applicable and practice.

\section{CONCLUSIONS}

The conclusions of seven aspects: (1) Good teaching scale, (2) Generic skill, (3) Students' motivation, (4) Learning resource, (5) Assessment appropriateness, (6) Students' workload, and (7) Curriculum contents are as follows:

The teaching quality was categorized fairly effective. However, students generally indicated to be dissatisfied with the teacher performance. They expected that teaching and learning process stimulates their motivation. The generic skills was categorized less effective where students recognized that they still lack of English and Arabic competence. The students were not highly motivated, as their awareness toward the importance of foreign language is still low. The learning resources for is not effective. They need the learning process which supported by some learning media, especially language laboratory. The assessment appropriateness is fairly effective. However, in some aspects, students expected that assessments techniques match their knowledge and skills they had learnt. They also need both summative and formative assessments can be used in balance in determining students' passing indicator. Students' workload was perceived less effective. The students in AD disagreed with the workload that they should perform and feel constrained to have a lot of assignments that involve their memory. Students perceived that the course book was not quite relevant with their needs. They expected that the course book should cover all aspect of language skills, particularly listening practice.
The result indicated that some indicators related to the teaching and learning in the LCC were not affectivity implemented. This certainly implies on: first, Pedagogical Implication; There is a need for passionate educator to become involved in improving assessment activities toward their students and developing their teaching skills for effective feedback to students. Many students highlighted assessment in their comments noting that they expect instructor to be fair and only to evaluate what had been thought. Students note that instructor should use variety of assessment and provide options so that students can express what they have learned. Students also wanted assessment techniques to match the knowledge and skills course objective. For instant, teacher should be enriched with pedagogical competences. Second, Practical Implication; The majority of students expected that learning resources support should be appropriately utilized as they are essential components for effective teaching and learning, particularly language laboratory. The stakeholders need to consider the importance of language laboratory that is beneficial to help students improve their language skills and sub skills and provide them with additional practice in all aspect that need to be reinforced. The issue of contents material within the LCC curriculum must be addressed. Simply the currents course book did not increase the motivation and performance of the majority of the students in this study. How the course book fit the students' expectations need to be much concerned regarding to develop students' basic foreign language competence because students' language skills development is largely a response to what the curriculum expect and how these expectations are communicated.

Based on the results of this study, there are some suggestions for future research. First, to obtain more in-depth responses from the participants, future research can be conducted on several study programs within various faculties in the SIIS SNJ Cirebon. Additional factors that might influence on students' perception of effective teaching such as environment, clear goals and standards, and gender perspective are also indicators that need to be explored. Second, further research also could be conducted in the LCC in relation with teachers' perception on effectiveness of the intensive English and Arabic program in the LCC. It becomes important to determine a balance and objective description of the LCC as it useful for evaluating the English 
and Arabic intensive program. Third, for a further research, mixed method design of the research might better to be conducted. Using a multiple methods can help researcher to examine process or problems from all sides. In this case, survey and interview method can be combined. The survey will help to gather quantitative information for the study. Besides, the in-depth interviews will assist in obtaining information that cannot be clearly expressed from the survey.

\section{REFERENCES}

Ainley, J. (2001). The 1999 postgraduate research experience questionnaire, Department of Education, Training and Youth Affairs (DETYA). Australian Council for Educational Research (ACER)

BC College \& Institute Student Outcomes Survey (BC CISOS) (2008). Understanding student satisfaction. Vol. 3 No. 1. Available at http://outcomes.ceiss.org/Publications/.

Brenes, C. A .N. (2006). The Language laboratory and the EFL course. Actualidades Investigativas en Educacion. (INIE). Vol. 6. No.2 Costa Rica: Universidad de Costa Rica.

Bystrom, H. N. E. (2004). Teaching evaluations at the introductory finance course at Lund University: A comparison of the Course Experience Questionnaire and a traditional Evaluation Approach. Lund: Lund University

Campbell, R.J. et al. (2004). Assessing teacher effectiveness: A differentiated model. London: Routledge Falmer.

Curriculum Development Council and the Hong Kong Examinations and assessment authority (CDC-HKEAA), (2007). English language curriculum and assessment guide (Secondary 4-6). English language education. Hong Kong: Key Learning Area.

Djemari MArdapi (2004). Pedoman khusus pengembangan instrument dan penilaian ranah afectif. Jakarta. Departemen Pendididkan Nasional.

Frej, F. \& Alkhatab, S. (2011). Assessing students' satisfaction with quality of service of students' information system.
IDEAS Research Division of the Federal Reserve Bank of St. Louis Vol. IX, Issue 1. available at http://www.mnmk.ro/documents/2011/1 0_Iordania\%20FFF.

Gedgrave, I. (1999). Modern teaching of physic. Delhi: Global Media Bhagirath Palace.

Hyland, K. (2006). English for academic purposes: An advanced resource book. London: Routledge.

Jenssen, W. J., Stensaker, B. \& Grogaard, J. (2002), "Student satisfaction: towards an empirical deconstruction of the concept", Quality in Higher Education, Vol. 88, No. 2, pp. 183-195.

Jones, J. (2003). Early literacy assessment systems: Essential elements. Princeton: Educational Testing Service (ETS), Research \& Development.

Kember, D \& Leung, D. Y. P. (2009). Development of a questionnaire for assessing students' perceptions of the teaching and learning environment and its use in quality assurance. London: Springer.

Kember, D. (2004). Interpreting students' workload and factors which Shapes Students' Perception of Their Workload. Journal in Studies in Higher Education Vol. 29 No. 2. Hong Kong: Carfax Publishing.

Killen, R. (2009). "Using direct instruction as a teaching strategy" in effective teaching strategies: lessons from research and practice $5^{\text {th }}$ ed. Melbourne: Electronic Reserve University of New England.

Kumaravadivelu, B. (2006). Understanding language teaching from method to post method. New Jersey: San Jose State University Lawrence Erlbaum Associates Publishers.

Leung, D. Y. P. \& Kember, D. (2009). Development of a questionnaire for assessing students' perception of the teaching and learning environment and its use in quality assurance. Learning Environ Res. 10.1007. Springer Science \& Business Media. B. V.

Nunan, T., Rigmor, G., \& McCausland, H. (2000). Implementing graduate skills as 
an Australian University, in Fallows, S., and Steven, C., (eds) Integrating Key Skills in Higher Education, London: Krogan Page

Pincas, A. et al. (2003). Teaching English as a foreign language. London: Routledge.

Root, E. (2009). Motivation and learning strategies in a foreign language setting: a look at a learner of Korean. Minnesota: University of Minnesota.

Scheerens, J. (2009). Improving school effectiveness. Fundamental of Educational Planning. No. 68. United Nation Educational, Scientific, and Cultural Organosation (UNESCO). Paris.

Sidhu, Gurnam Kaur, 2003. Literature in the language classrooms: Seeing through the eyes of learners. In: Ganakumaran \&
Edwin Malachi (eds.). Teaching of literature in ESL/EFL. contexts. pp. 88110. Petaling Jaya: Sasbadi-Melta ELT Series.

Tampakis, A. \& Vitoratos, E. (2009). Estimation of students' workload correlation of teaching and learning methods with examination. Internationalization and the Role of University Networks Proceedings of the EMUNI Conference on Higher Education and Research: Vol. 9 No. 6. Portoroz.

Ur, P. (2009). A course in language teaching: practice and theory. Cambridge: Cambridge University Press.

Weisman, M. E. \& Dunlap, C. Z. (2006). Helping English language learners succeed. Huntington: Shell Education. 